\title{
Historein
}

Vol 10 (2010)

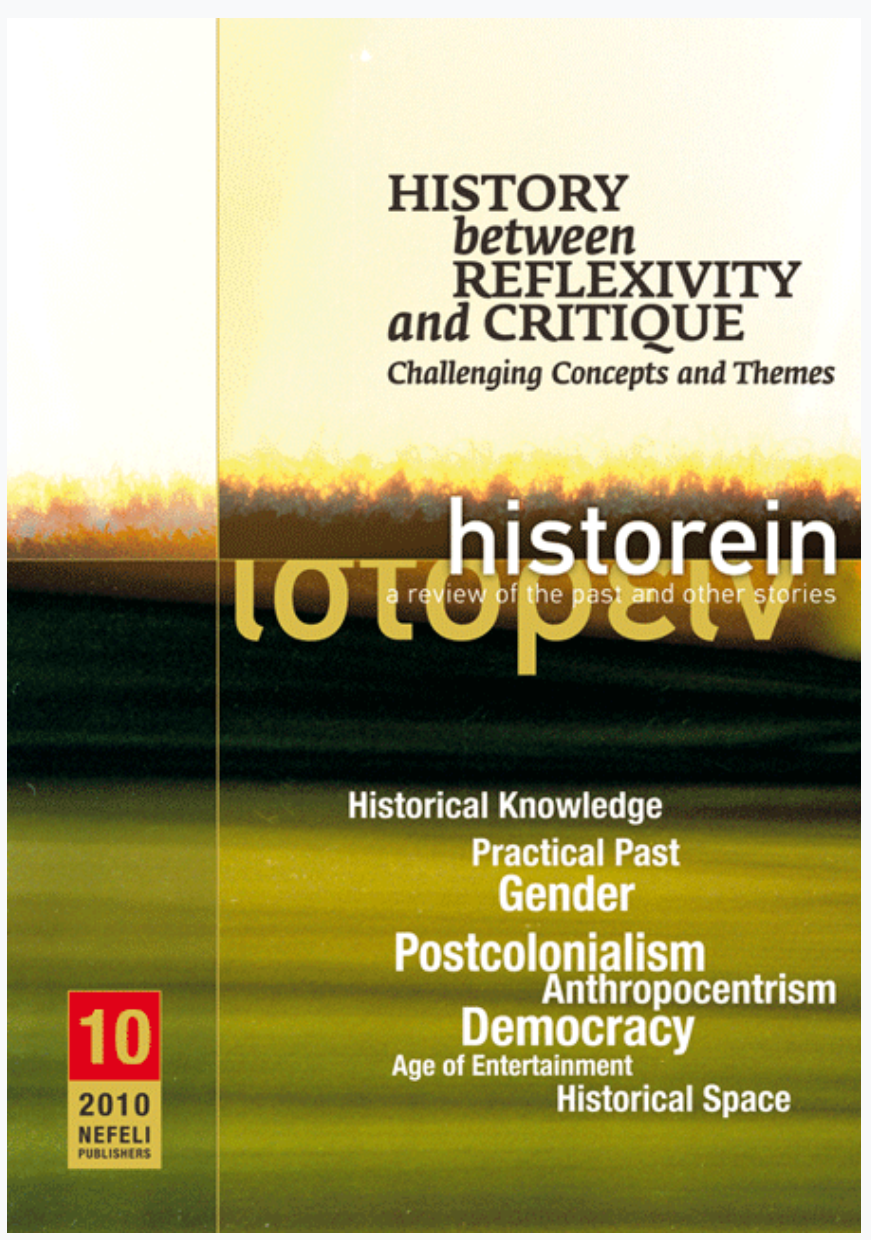

\section{Historiography and Nonwestern Pasts}

\section{Sanjay Seth}

doi: $10.12681 /$ historein.7

\section{and CRITIQUE}

\section{doi: $10.12681 /$ historein.7}

History between Rellex 
When the discipline of history came to be formalised and institutionalised in nineteenth-century Europe, it was assumed that historiography was superior to, and would displace, the many modes by which peoples in different times and places had re-presented their pasts to themselves. Historiography would displace these forms of remembering and representing the past because it had an epistemological warrant that they did not. The assumed epistemological superiority of historiography rested, for the most part, on a series of oppositions between fact and fancy, between evidence, or hearsay and superstition, and between objectivity and bias. The modern historical enterprise thus presumed that an object called "history" exists, and because it does, that it can be objectively represented, and assumed that "real" history-writing is qualitatively different from epic, legend and myth.

I start this article from the premise that it is not the case that history simply "is", and historiography is the best way of representing the past. It is not that history simply happens, and historiography is the attempt to recreate that happening through a rigorous method. Rather, historiography is an intellectual and cultural construct, one particular way of construing and constructing the past; at once a tradition of reasoning, a way of being, and a certain practice of subjectivity. The desire to write history is specific to certain people (societies, classes) and not others. It is connected to some phenomena - the emergence of the modern state, "progress", scientific rationality and not others, which it usually defines it-

\section{Historiography and} Nonwestern Pasts

\section{Sanjay Seth}

Goldsmiths, University of London 
self against (magic, gods). And I will conclude this essay by suggesting that this way of construing and representing the past is not always adequate to nonwestern pasts.

\section{The code of history}

It has often been pointed out that history is unusual in that the term for the discipline simultaneously designates its object. Underlying this happy coincidence - as has also been pointed out - is an epistemological naïveté, one according to which history, unlike other disciplines, has no need to think its object, because its object simply is. History-as-fact simply happens, and history-as-discipline is an attempt to recreate that happening to the degree that documents allow us to do so. The result, as Louis Althusser pointed out long ago,' is that the discipline of history takes methodology for its theory, and historiographical debates are more often than not debates over the "craft" of history. But this naivete cannot obscure the fact that history as a discipline is not so innocent of preconditions. The past is not forever available to the present, a mute entity waiting for the historian to give it voice. History-writing is not simply a "craft" that is applied to a preexistent, natural object, but rather, like any discipline, it conceives and constructs its object.

If history-writing constitutes its object, then how does it constitute that object? Various answers to this can and have been given, including Lévi-Strauss' famous answer that the code of history is chronology, ${ }^{2}$ and the claim made by others that historiography codes/effects an absolute divide between a dead past and the present. ${ }^{3}$ Both of these are important and defining features of the code of history, but more important still, and above all else, historiography encodes the humanism or anthropology that has become a defining feature of western thought from the early modern period. It does so, first of all, inasmuch as its subject is man. This seems unremarkable - who else could the object of history be, if not man? Tracing the semantic and epistemic changes underlying the emergence of the concept of history, Reinhart Koselleck however notes that prior to the Enlightenment "there was no history for which humanity might have been the subject", 4 but rather histories in the plural, of specific institutions and communities. The emergence of historiography thus corresponds to the emergence of a "collective singular" - man - as the object of history.

That historiography emerges as the study of the past of man also means that nature no longer has a history. Voltaire's essay on "Historie" in the Encyclopédie, for example, declares that "natural history" is in fact a part of physics, not history. More generally, "historia naturalis" ceased to belong to the domain of history. ${ }^{5}$ Gods are also expelled from the domain of history. This is not a function of secularisation, for historiography can coexist with religion, and indeed even, as in Ranke's case, with the conviction that a divine providence animates history. But God or gods can no longer be historical actors, because the subject of history is man, and only man. It is this anthropological/humanist presumption that disqualifies many of the other forms by which peoples have conceived and narrated their past - these are now declared not to be history-writing at all, and indeed the emergent discipline defines itself against them. It also means that not only is God not a historical actor, he is himself to be explained as a creature of men.

This last is one of the more dramatic implications of an epistemic and cultural shift which, 
among its other effects, saw the ways by which European men and women recounted their past replaced by this new "code". "The task of the modern era," wrote Ludwig Feuerbach, is "the humanization of God - the transformation and dissolution of theology into anthropology."' The modern era has been steadily discharging that task. Once, to understand men you had to understand God; now, to understand the gods of men you have to understand the men, for their gods are the fantastical creation of their minds. Once, the purposes and the acts of gods explained the world of men; now, gods are themselves signs of men, traces from which historians, anthropologists and sociologists can recreate the meanings and purposes with which these men endowed their world. It is not, then, only that the subject of history is man, but that this subject is a Subject, that is, a meaning- and purpose-endowing being who objectifies himself in the world, and through whose objectifications we can recreate what sort of men these were, and what sort of world they had created and inhabited.

To be sure, there are important differences in how this is formulated. In some cases, the signs which give us information about their makers are understood as an "objective spirit"; in others, collectively they constitute a "culture"; in others still, these are the signs which make up the social text. In some versions, the fact that men are authors means that their productions are more or less transparent to them, or will become so once man produces the conditions of his life and his own nature under conditions of freedom; for others, we are the products of our own productions, but these operate in ways which are opaque to us and partly beyond our control and determination. Different disciplines constituted on the basis of these founding presumptions also operationalise or mobilise them in different ways. In the case of historiography, the specific form in which anthropological assumptions are encoded can be clearly seen in the fetishistic concern with the primary source, the text or text analogue which, after Ranke, was seen to define historiography as it came to be institutionalised as a discipline. Attention to primary sources is the essence of historiography, not principally because this is more "rigorous" than earlier methods but because the idea has become naturalised that these are remnants that objectify the meanings and purposes of historical actors, from which we can piece together the past. Thus, Marc Bloch wrote that "it is men that history seeks to grasp", ${ }^{7}$ and that it achieved this through "a knowledge of their tracks. Whether it is the bones immured in the Syrian fortifications, a word or form whose use reveals a custom, a narrative written by the witness of some scene ... what do we

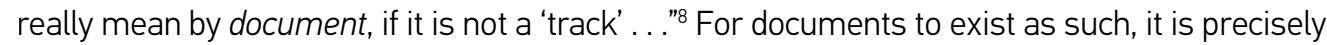
necessary that they be seen as "survivals", as "tracks", as "traces". Only when we see the score of a Beethoven symphony as something surviving from the past that might be mined for information about music, court culture and many other things besides - rather than as wrapping paper - does it become a document. That is precisely why even documents which are of dubious value for the direct information which they contain - forgeries are an extreme instance - are nonetheless of historical value, for they can, as traces, be made to yield other sorts of information.?

\section{A "transcendental presupposition"}

Historiography thus "encodes" anthropological presumptions with specific reference to the object it constructs and of which it purports to offer knowledge, namely the past. Historiography is 
by no means the only site where this epistemic and cultural transformation, one which marks the birth of modern, western knowledge and culture, came to be effected. The transformation in question is very much wider. One after another, modern writers of diverse philosophical affiliations, working from within different disciplines - Vico, Herder, Tylor, Cassirer, Geertz, Dilthey, Greenblatt and the "New Historicism", and numerous others - testify that behind most things lurks man; that art and literature, religion and morality and myth, law and custom, and common sense are all "products", "expressions" or "traces" of "societies" or "peoples" or "cultures". I have designated this shift, in shorthand form, as anthropology/humanism. As observed, what precise form these presumptions take varies across authors and also according to discipline. The differences are important, but underlying them is a more basic commonality, a shared epistemological space. Max Weber characterised it thus: "The transcendental presupposition of every cultural science ... is that we are cultural beings, endowed with the capacity and the will to take a deliberate attitude towards the world and to lend it significance."10

I cite Weber not only because "transcendental presupposition" is a particularly apt formulation but also because Weber recognises that the adoption of this presupposition marks a cultural and epistemic transformation, a shift from seeing the world as a text, imbued with meaning and purpose, of which men, as creatures made in God's image and endowed with grace and reason, are privileged readers, to the view of the world as a social text of which men are the authors. In Weber's account this presupposition arises with the "disenchantment of the world", where modern men and women in the Occident recognise that they are cultural beings who endow the world with significance precisely because, and in proportion to, the fact that they are forced to recognise that there are no meanings already in the world waiting to be "discovered": "The fate of an epoch which has eaten of the tree of knowledge is that it must know that we cannot learn the meaning of the world from the results of its analysis, be it ever so perfect; it must rather be in a position to create this meaning itself."11 This has not always been presumed, and thus this disenchanted outlook has a history, consisting in the specific form that rationalisation took in Occidental religions, culminating in Protestantism and the social and scientific developments with which it was associated.

But if the realisation that we endow meaning on the world has a history: in what sense is this a transcendental presupposition? That is, if it is borne of the specific history of the modern West, how can it be said to be a presupposition of universal import? For example, if in the past men and women in Europe saw God as the source of reality and of meaning, whereas we disenchanted moderns do not, then by what warrant do we privilege our presupposition, and conclude that their God has to be understood and explained as meanings they endowed their world with, rather than that which gave them life and the world meaning? And by what right do we do so for the nonwestern world, which may not have undergone the same processes of rationalisation, culminating in the disenchantment of the world?

The answer, according to Weber, is that while we moderns have come to the realisation that the world is disenchanted as a consequence of a very specific (Occidental) history, humans have always been the producers of meanings and purposes, even when they have not realised it. David Kolb writes, "In Weber's eyes, modernity is an explicit recognition of what the self and society 
have been all along. Modern identity is not just another in a sequence of historic constructions; it is the unveiling of what has been at the root of these constructions."12 From this perspective, it is enchantment, as intellectual "error", that needs "explaining"; the disenchantment of the world, while it has a history, is the truth finally uncovered. As with other moderns, Weber sees modernity as a privileged vantage point that finally makes comprehensible all the history that preceded it.

Weber's analysis of disenchantment is deeply indebted to Nietzsche. When Nietzsche has a madman announce the death of God, and when he announces the advent of nihilism and the destruction of values, he too is announcing that belief in a transcendent realm of values, in God, in Platonism, is nearing its end. At times he sounds like an upbeat Weber, one who welcomes and celebrates this development, because it allows man to recognise as his that which he once attributed to others:

All the beauty and sublimity we have bestowed upon real and imaginary things, I will reclaim as the property and product of man; as his fairest apology. Man as poet, as thinker, as God, as love, as power; 0, with what regal liberality he has lavished gifts on things, only to impoverish himself and make himself feel wretched! His most unselfish act hitherto was to admire and worship and to know how to conceal from himself that it was he who created all that he admired. ${ }^{13}$

The transcendent values to which men have subordinated themselves have in fact always been their own products; every discovery was in fact an invention, every interpretation a new creation. Nietzsche thinks a recognition of this fact affords the possibility of a freedom to revalue all values, recognising them all as human creations. But there is an important difference between Nietzsche and Weber, and it does not simply lie in the fact that Nietzsche views with gaiety and lightness what Weber announces with foreboding. The Genealogy of Morals and other writings provide also a genealogy of the subject, not as a natural being whose essence is to be possessed of consciousness and the capacity to create meaning but as someone created to be able to make promises, to feel guilt, to subscribe to values, and the like. Thus for Nietzsche - albeit inconsistently so - the subject is not the source and origin of meaning and value, but is himself a historical product, forged on the anvil of Christian morality and Roman law. Weber assumes that the value-creating or culture-secreting individual has always existed, but only becomes aware of himself as such in modern times, whereas for Nietzsche this individual is himself a creation or invention. The difference is significant, because if the presumption that humans are the source of all values and meanings is in fact historically and culturally produced, then we may not be entitled to presuppose it where such a subject has not been created.

This is Heidegger's position. Heidegger rejects all talk of Weltanschauung and of different ways of "picturing" the world, precisely because this assumes that men have always pictured the world and ascribed value to it. The difference between the medieval and modern worlds is not, however, that modern men and women picture the world differently and have different values. To see the world as a picture, to have values and cultures and experiences, are not transcendental presuppositions which have finally come into their own but are rather a consequence of cultural and epistemic shifts, including the rise of a metaphysics of subjectivity that Heidegger labels "anthropology": 


\section{Historiography and Nonwestern Pasts}

That the world becomes picture is one and the same event with the event of man's becoming subiectum ... the more extensively and the more effectively the world stands at man's disposal as conquered, and the more objectively the object appears, all the more subjectively ... does the subiectum rise up, and all the more impetuously, too, do observation and teaching about the world change into a doctrine of man, into anthropology. It is no wonder that humanism first arises where the world becomes picture ... Humanism, therefore, in the more strict historiographical sense, is nothing but a moral aesthetic anthropology. The name "anthropology" as used here ... designates that philosophical interpretation of man which explains and evaluates whatever is, in its entirety, from the standpoint of man and in relation to man..$^{14}$

The contemporary antihumanists who are the heirs of Nietzsche and Heidegger similarly insist that man, far from always having been a value-creating and meaning-producing being who, with modernity, finally becomes aware of that fact, is himself a historically produced, and possibly transient, consequence of contingent historical events. One effect of such analyses is that historiography is immediately rendered problematic: if man is a product of history, he cannot be the constant whose changes and transformations it retells. Indeed, analyses of this sort reverse our normal sequence of cause and effect, suggesting that it is not because man is the origin and source of meaning and values that he is the subject of anthropology and history, but rather that it is this presupposition and its correlates, embedded in our culture and our thought, that serve to create and secure humanism and anthropology. Historiography is one of the important means by which, and sites on which, this is achieved. "Making historical analysis the discourse of the continuous and making human consciousness the original subject of all historical development and all action," according to Michel Foucault, "are two sides of the same system of thought," one characterised by "the sovereignty of the subject and the twin figures of anthropology and humanism". ${ }^{15}$ Indeed, history-writing has an especially important function to fulfil, for as this humanism and anthropology have come to be assailed in the study of language, myth, sexuality and kinship, historiography becomes "the last resting-place of anthropological thought", ${ }^{16}$ or in Lévi-Strauss' words, "the last refuge of a transcendental humanism". ${ }^{17}$

\section{Hermeneutics, historiography and nonwestern pasts}

If Weber's transcendental presupposition cannot in fact be presupposed, if it confuses cause with effect, then this constitutes a problem for the code of history whenever it is applied to an object where the anthropological presumptions of the code are absent. Michel de Certeau points out that when historians study religion, they take it as their task to ask what religion tells us about the society from which it sprang. They assume, that is, that "society" is the axis of reference that will render religious phenomena intelligible, whereas for their subjects religion was (often) what made society intelligible:

The religious history of the seventeenth century ... implicates a difference between two systems of representation, one "social" (so to speak) and the other "religious"; that is, between two periods of consciousness, or between two historical types of intelligibility, our and theirs. Thus, we have to wonder what may be the meaning of an enterprise that 
consists of "understanding" a time organized as a function of a standard of comprehension other than ours. [For in this, our,] perspective, "comprehending" religious phenomena is tantamount to repeatedly asking something else of them than what they meant to say ... taking as a representation of the society what, from their point of view, founded that society ... ${ }^{18}$

The study of a past that is significantly "other" is in this case characterised by a reversal which Certeau renders through a metaphor drawn from chess: "Between their time and ours, the signifier and the signified have castled. We postulate a coding which inverts that of the time we are studying." ${ }^{19}$ As a modern, rational practice, historiography cannot accord God the role of a historical actor, and thus we translate seventeenth-century understandings into our terms. Far from being defined by its avoidance of "anachronism", history-writing as discipline and practice is in fact based on anachronism, continually translating the understandings of historical subjects into our modern, anthropological understanding. But the converse is also true; our historical practice is not an ex nihilo creation, but arises out of previous debates - "when they refer to their own practices... historians discover constraints originating well before their own present, dating back to former organisations of which their work is a symptom, not a cause."20 "Our" historical discourse is a product of those debates and processes which, beginning four centuries and more ago, rendered religion into a phenomenon susceptible to sociological explanation, rather than regarding the human world as one to be understood in terms of divine instigation.

Just as the "model" of religious sociology implies, among other things, the new status of practice or of knowledge in the seventeenth century, so do current methods - erased as events and transformed into codes or problematic areas of research - bear evidence of former structurings and forgotten histories. Thus founded on the rupture between a past that is its object, and a present that is the place of its practice, history endlessly finds the present in its object and the past in its practice. ${ }^{21}$

Hans-Georg Gadamer has argued that all encounters with past texts and text-analogues are intrinsically interpretive, and that all interpretation in the human sciences is intrinsically historical. All encounters with the past occur within a tradition, and if history-writing is practiced in a hermeneutical rather than positivist and objectifying way, it can lead to greater self-consciousness of that tradition. If we translate Certeau's observations into Gadamerian terms - recognising that to do so is not to stay with Certeau's thought - we could say the following: When we encounter a text from, say, seventeenth-century Europe, one which explains society and its functioning in terms of God, the distance between the text and our historical situation cannot be bridged by cancelling one of the terms. Understanding is achieved neither by imposing our current understandings on the text (for example, by treating God as a "projection" and/or as ideology), nor can we seek, as romantic hermeneutics would, to recreate the context and meaning of that text in order to restore it to its original meaning and intention. An acknowledgement of the historicity of our own understanding means that we cannot accord our categories of interpretation any privilege; but the same acknowledgement of the historicity of our understanding means there is no way of encountering the text "in its own right". Because this is something more than an epistemological dilemma, it is capable of "resolution". The text is not just an object of the past belonging purely to the present, for it comes to us already interpreted, not as a mere object, but 
as a tissue of interpretations. We must remain open to its "truth", and if we become convinced of this, it forces us to rethink our current understandings, and to redescribe the tradition through which it arrives to us. However if, as is more likely in this case, we find ourselves unable to reach an agreement with the text - if there can be no fusion of horizons - we are then entitled to try and situate it in terms of its context. But even here, the end point is not the same as it would be had we dismissed the truth of the text from the beginning, for we have reencountered and have arrived at a better understanding of our relation to a tradition in which God once bestrode the world and made it in his image, but which later gave way to a "secular" view in which God had his historical agency withdrawn from him. The "former structurings and forgotten histories" which have brought us to our present historical situation are no longer "forgotten"; they have been disinterred and reexamined, and we have arrived at a better understanding of the tradition through which we speak as a result of this encounter. History "finds the present in its object and the past in its practice" self-consciously, as a result of such a dialogic encounter, even where, as in this instance, we cannot acknowledge the truth of the text nor achieve a fusion of horizons.

I am enquiring into what it means, using the code of history, to write about those who do not live by that code or recognise themselves in it. I have argued that this question arises not only with reference to the nonwestern world but also with reference to premodern Europe. To explain the world of men and women of medieval times historically is to translate their understandings into our terms, or to repeat Certeau's words, is to "postulate a coding which inverts that of the time we are studying". However this exercise, while anachronistic, is nonetheless productive; even where we cannot accept the "truth" of texts from the past, we gain better self-understanding, that is, understanding of the tradition out of which we reason.

The same is not true when we apply the code of history to nonwestern pasts, for the simple reason that the object of enquiry does not belong to the same tradition as the enquiring subject. ${ }^{22}$ To write a history of, say, India from within western knowledge is to confront the fact that the "now" from which we write is not itself linked in a thousand ways to the "then" of those of whom we write, because a profound caesura separates the two; the tradition from which we write is not the same as that of which we write. Thus, what might serve to validate the anachronism which is an inescapable feature of historiography even when it encounters European pasts is not true here, because, in this case, history "finds the present in its object", but it does not find an Indian "past in its practice".

The knowledge from which we write a history of India is not continuous with the knowledges and intellectual traditions of India. These intellectual traditions had not died of inanition when the British first came to India; as late as the seventeenth century there was an explosion of scholarly writing in Sanskrit, testifying to the vitality of an extraordinarily long and continuous intellectual tradition. Some of the navya or new scholars of that time self-consciously saw themselves as effecting innovations; but they were still heirs to a tradition going back two millennia, which they actively engaged, disputed with and developed. The same in not true of historiography, for neither the Sanskrit tradition(s), nor any other indigenous tradition, found an echo in the code of his- 
tory by which we write of Indian pasts. This code was an imposition; it did not engage with Indian traditions, did not refute them and thereby displace them. Its victory was won cheaply, through administrative fiat, when in 1835 India's British rulers decided that only that education which sought to disseminate modern, western knowledge through modern institutions and pedagogic processes was to receive government patronage; and that the teaching of modern history was to replace the indigenous Puranic "histories" which Thomas Babington Macaulay characterised and dismissed as "abounding with kings thirty feet high and reigns thirty thousand years long, and geography made of seas of treacle and seas of butter".23

As a result, the code of history cannot even fulfil the hermeneutic function that it fills elsewhere, that of being one of the modes by which men and women of the West can, through the self-consciously anachronistic exercise of translating the lives and worlds of their dead forebears into their own terms, illuminate both what connects and separates them from this past and these forebears. In India that role continued to be performed by the genealogist, the balladeer, and the storyteller, who interpreted and refurbished the tradition to which they belonged by retelling the past. ${ }^{24}$ The historian, however, was closer to the position of the colonial official (many of whom, like James Mill and Macaulay, were also historians); she was discontinuous with, and in a position of pure externality to, the pasts of which she wrote.

\section{Conclusion}

In this article I have suggested that anthropology/humanism has fostered an illusion, mistaking effect for cause; that it is not because there is man that the sciences of man have arisen, but that it is the latter that encode, and thus serve to produce and secure, humanism. In characterising modern thought as anthropological, Nietzsche, Heidegger, Foucault and other writers I have drawn on to develop my argument also offer a critique of this anthropological presumption. For instance, they argue that the subject is neither sovereign nor transparent to himself; that just as he is an effect of certain events, he may one day disappear. I am sympathetic to these arguments, but here I have invoked them for their characterisation, rather than for their critique. I suggest that the assumption that man is a creator of meanings and values is not a "transcendental presupposition" we are entitled and even obliged to make, but is rather a form of "transcendental narcissism", ${ }^{25}$ one of the means by which the modern West creates and secures the anthropological/humanist theme that man is the source and origin of meaning and value - and hence the subject of history. Nonetheless, inasmuch as this humanism is in fact secured, inasmuch as the West is dominated by a metaphysics of subjectivity, inasmuch as the presupposition that man is the source and origin of meaning, value and purpose is found in a wide range of practices and institutions and intellectual activities, then a historiography founded on similar premises is an appropriate way for such societies to conceive of their past and represent it to themselves.

Whether such premises are also valid for writing histories of nonwestern cultures will depend on whether such presuppositions found a home there. That is, it will depend on whether the "transcendental narcissism" of the West succeeded in also becoming a narcissism in the East; wheth- 
er this "white mythology", as Derrida terms it, ${ }^{26}$ also became part of the mythos of the nonwhite world. ${ }^{27}$ Since this has only partially occurred, post-Enlightenment historiography may not be adequate for the task of representing Indian pasts. I suggest then that the code of history is but one way of representing the past, and a recent one. It is eminently useful even where anachronistic, for when written in a hermeneutic mode, it can be a way of engaging, better understanding, and developing and refurbishing the intellectual tradition(s) to which we belong, and out of which we reason. But this is only true where the code of history is applied to the pasts out of which this code itself developed; applied to other pasts, it is neither the "right" way of recounting these pasts, nor does it illuminate the traditions of the peoples whose pasts these are.

Traditions are not hermetically sealed of course. The civilisation of medieval and early modern India was itself a palimpsest, born of the meeting of the culture, knowledges and institutions to which the subcontinent had been home, and those the Turk and Afghan and Persian invaders brought with them. If we are willing to allow for the existence of a "western tradition" stretching back to a time long before there was any conception of "Europe" or the West, this was a tradition that includes the collapse of Rome and the fusion of Roman law with barbarian institutions, the later revival of Greek learning, and the synthesis of Aristotelianism and Christianity effected by St Thomas. Moreover, this and the traditions of India never developed in complete isolation from each other; and for some four hundred years now the ways of the western barbarians have been finding a home in India. A fusion of traditions may yet occur, and out of this a new tradition may yet be founded. However, historiography today cannot assume that this has already occurred. For now, to write history in a western mode with even a modicum of self-consciousness is to be continually reminded not only that one is writing from a historical now which is very different from that of the object of study, but also that this difference is not the space of a dialogue where we simultaneously refurbish and reconsider the tradition within which we are located, but that it marks a profound break, the full implications of which historiography has yet to register, let alone begin to seriously consider.

\section{NOTES}

1 Louis Althusser and Etienne Balibar, Reading Capital, London: New Left Books, 1970, 109.

2 Claude Lévi-Strauss, The Savage Mind, London: Weidenfeld and Nicolson, 1972, 258.

3 Constantine Fasolt provides an admirably lucid description of the "basic principles" that the practice of history encodes: "That the past is gone; that it can nonetheless be turned into an object of scholarly examination by means of evidence; that the evidence was produced by some specific agent at some specific time and place for a specific purpose; that scholarly examination can take advantage of the agent's responsibility for the evidence to reconstruct its meaning; that evidence must therefore be interpreted in the context of its time and place; and above all, that things do have a time and place that may be called their own." The Limits of History, Chicago: University of Chicago Press, 2004, 222.

4 Reinhart Koselleck, Futures Past, trans. Keith Tribe, Cambridge: MIT Press, 1985, 200.

5 Ibid., 296.

6 Ludwig Feuerbach, "Principles of the Philosophy of the Future", in The Fiery Brook: Selected Writings of 
Ludwig Feuerbach, trans. Zawar Hanfi, New York: Anchor Books, 1972, 177 (para/aphorism 1).

7 Marc Bloch, The Historian's Craft, trans. P. Putnam, Manchester: Manchester UP, 1979, 26.

8 Ibid., 55.

9 In Oakeshott's elegant formulation, "a record never lies; even if it does not mean what it says it may be made to say what it means." "Three Essays on History", in On History and Other Essays, Oxford: Blackwell, 1983.

10 Max Weber, "Objectivity in Social Science and Social Policy", in Edward Shils and Henry Finch (eds), The Methodology of the Social Sciences: Max Weber, New York: Free Press, 1949, 81. Earlier in the same essay Weber makes clear that what he defines as the cultural sciences encompass what are traditionally defined as social sciences (67).

11 Weber, "Objectivity in Social Science and Social Policy", 57.

12 David Kolb, The Critique of Pure Modernity, Chicago: University of Chicago Press, 1986, 9-10.

13 From Will to Power, quoted in Heidegger, Nietzsche, vol. 4, Nihilism, trans. F.A. Capuzzi, San Francisco: Harper and Row, 1982, 81.

14 Martin Heidegger, "The Age of the World Picture", in The Question Concerning Technology and Other Essays, trans. William Lovitt, New York: Harper Torchbooks, 1977, 133.

15 Michel Foucault, The Archaeology of Knowledge, New York: Harper Colophon, 1972, 12.

16 Ibid., 14.

17 Lévi-Strauss, The Savage Mind, 262.

18 Michel de Certeau, The Writing of History, trans. Tom Conley, New York: Columbia UP, 1988, 138. The two paragraphs quoted here appear in the reverse order in the original, but the emphasis is in the original.

19 Ibid., 138.

20 Ibid., 36.

21 lbid.

22 As Walter Mignolo observes, "The understanding of 'our' tradition, in which the foundation of philosophical discursive hermeneutics rests, implies that the tradition to be understood and the understanding subject are one and the same." The Darker Side of the Renaissance, 2nd ed., Ann Arbor: University of Michigan Press, 2003, 11.

23 Minute recorded by Macaulay, law member of the Governor-General's Council, 2 Feb 1835, reprinted in Lynn Zastoupil and Martin Moir (eds), The Great Indian Education Debate: Documents Relating to the Orientalist-Anglicist Controversy, 1781-1843, Richmond: Curzon Press, 1999, 166.

24 For a brief but illuminating comment on this, see Ranajit Guha, "The Authority of Vernacular Pasts", Meanjin 51:2 (1992): 299-302.

25 Foucault, The Archaeology of Knowledge, 203.

26 Jacques Derrida, "White Mythology: Metaphor in the Text of Philosophy”, Margins of Philosophy, trans. Alan Bass, Brighton: Harvester Press, 1982.

27 On this see Sanjay Seth, Subject Lessons: The Western Education of Colonial India, Durham: Duke UP, 2007. 